\title{
Indigenous Plasmids of Pseudomonas syringae pv. mori, the Causal Agent of Bacterial Blight of Mulberry
}

\author{
Mamoru Sato*, Brian J. Staskawicz** \\ and Nickolas J. PANOPOULOS*** \\ 佐藤 守*・Brian J. Staskawicz** - Nickolas J. Panopoulos***: \\ クワ縮葉細菌病菌 Pseudomonas syringae pv. mori のプラスミド
}

\begin{abstract}
Strains of Pseudomonas syringae pv. mori, the causal agent of bacterial blight of mulberry, contain 2 to 4 indigenous plasmids ranging from approximately 4.5 to 70 mdal and were classified into 9 groups according to their characteristic plasmid patterns. A survey of 17 isolates did not reveal apparent correlations between plasmid pattern and toxigenicity, phage sensitivity or other phenotypes tested. All strains tested accepted freely the non-conjugative plasmid RSF1010 through mobilization by naturally occurring conjugative plasmid $\mathrm{pBPW} 1$ of P. s. pv. tabaci BR2, but re-transferred RSF1010 into Esherichia coli at very low frequency. Thus, it seems to be indicated that they possess an indigenous fertility system which is either naturally repressed or mobilizes RSF1010 with low efficiency.
\end{abstract}

(Received June 30, 1981)

Key Words: Pseudomonas syringae pv. mori, plasmid.

\section{Introduction}

Indigenous plasmids have been reported in several plant pathogenic bacteria including a number of Pseudomonas syringae pathovars ${ }^{5,8,10,20)}$. Furthermore, it has been shown that plasmid pTi and pIAA 1 controls the pathogenicity of Agrobacterium tumefaciens ${ }^{18,19)}$ and of p. syringae pv. savastono $i^{2)}$, respectively. Although evidence for the involvement of plasmid in pathogenicities of other phytopathogenic bacteria is lacking ${ }^{9)}$, the subject is of considerable interest in the genetic analyses of pathogenicities of these bacteria.

The presence of indigenous plasmids of P. syringae pv. mori (abbrev. P. s. mori), the causal agent of bacterial blight of mulberry, has not been reported previously. This report summarizes our preliminary results concerning the detection and characterization of plasmids in this bacterium.

\footnotetext{
* The Sericultural Experiment Station, Yatabe, Ibaraki 305, Japan 農林水産省亘糸試験場

** International Plant Research Institute, San Carlos, CA 94070, U. S. A.

*** Department of Plant Pathology, University of California, Berkeley, CA 94720, U. S. A.
} 


\section{Materials and Methods}

Media. King's B medium $(\mathrm{KB})^{4)}$ was used to grow the bacteria and to perform plate matings. Genetic crosses were performed on $\mathrm{KB}$ or Minimal A-glucose agar medium $^{7)}$ supplemented with streptomycin (15 to $20 \mu \mathrm{g} / \mathrm{ml}$ ) and/or rifampicin (100 $\mu \mathrm{g} / \mathrm{ml}$ ). For E. coli recipients the selections were performed on $\mathrm{KB}$ agar containing the appropriate antibiotics by incubating at $37 \mathrm{C}$ or $40 \mathrm{C}$ (both temperature are nonpermissive for growth of $P$. s. mori).

Bacteria and Plasmids. The bacterial strains used in this study are listed in Table 1. All isolates of P. s. mori including the "halo blight" strain" ${ }^{17)}$ were virulent

Table 1. Tested bacterial isolates

\begin{tabular}{|c|c|c|}
\hline Bacterial isolates & Properties $^{a)}$ & Source \\
\hline \multicolumn{3}{|l|}{ Pseudomonas syringae } \\
\hline \multicolumn{3}{|l|}{ pv. mori } \\
\hline S 6801 & $\operatorname{Vir}^{+}$ & Sato et $a l .{ }^{14)}$ \\
\hline S 6802 & $\operatorname{Vir}^{+}$ & "I \\
\hline S 6803 & $\operatorname{Vir}^{+}$ & "I \\
\hline S 6804 & Vir $^{+}$ & "I \\
\hline S 6805 & $\operatorname{Vir}^{+}$ & "I \\
\hline S 6806 & $\operatorname{Vir}^{+}$ & "I \\
\hline S 6807 & Vir $^{+}$ & "I \\
\hline S 6808 & $\operatorname{Vir}^{+}$ & "I \\
\hline S 6809 & $\operatorname{Vir}^{+}$ & 11 \\
\hline S 6810 & $\operatorname{Vir}^{+}$ & "I \\
\hline M 5 & $\operatorname{Vir}^{+}$ & Sato ${ }^{11)}$ \\
\hline S $6914-1$ & $\mathrm{Vir}^{+}$Non-motile & Sato and Takahashi ${ }^{12)}$ \\
\hline S 6801 rif & $\operatorname{Vir}^{+} \operatorname{Rif}^{r}$ & Spontaneous mutant, this study \\
\hline S 6802 rif & $\operatorname{Vir}^{+} \operatorname{Rif}^{r}$ & $" 1$ \\
\hline S 6803 rif & $\operatorname{Vir}^{+} \operatorname{Rif}^{r}$ & "I \\
\hline S 6804 rif & $\operatorname{Vir}^{+} \operatorname{Rif}^{r}$ & "I \\
\hline S 6809 rif & $\operatorname{Vir}^{+} \operatorname{Rif}^{r}$ & "I \\
\hline M 5 rif & $\operatorname{Vir}^{+} \operatorname{Rif}^{r}$ & "I \\
\hline S 6914-1 rif & $\operatorname{Vir}^{+} \operatorname{Rif}^{r}$ & "I \\
\hline \multicolumn{3}{|l|}{ pv. mori } \\
\hline \multicolumn{3}{|l|}{ halo blight strain } \\
\hline S $7133-2$ & $\operatorname{Vir}^{+}($Halo $)$ & Takahashi and Sato ${ }^{17)}$ \\
\hline S $7133-3$ & $\operatorname{Vir}^{+}($Halo $)$ & "I \\
\hline S 7233-1 & $\mathrm{Vir}^{+}($Halo $)$ & "I \\
\hline S 7233-2 & $\operatorname{Vir}^{+}($Halo $)$ & "I \\
\hline S 7233-3 & $\operatorname{Vir}^{+}($Halo $)$ & "I \\
\hline S 7133-2 rif & $\mathrm{Vir}^{+}($Halo $) \mathrm{Rif}^{\mathrm{r}}$ & Spontaneous mutant, this study \\
\hline S 7133-3 rif & $\operatorname{Vir}^{+}($Halo $)$Rif $^{r}$ & 11 \\
\hline S 7233-1 rif & $\operatorname{Vir}^{+}($Halo $)$Rif $^{r}$ & "1 \\
\hline S 7233-2 rif & $\operatorname{Vir}^{+}($Halo $)$Rif $^{r}$ & "I \\
\hline S 7233-3 rif & $\operatorname{Vir}^{+}($Halo $) \operatorname{Rif}^{r}$ & "I \\
\hline \multicolumn{3}{|l|}{ pv. tabaci } \\
\hline BR2 (RSF1010) & $\mathrm{Sm}^{r}, \mathrm{Su}^{\mathrm{r}}$ & Staskawicz et $a l .^{16)}$ \\
\hline \multicolumn{3}{|l|}{ Esherichia coli } \\
\hline SK 1592 & $t h i^{-}, \mathrm{hsdR}^{-}, \mathrm{hsdM}^{+}$ & \\
\hline V 517 & & Macrina et $a l .^{6)}$ \\
\hline
\end{tabular}

a) Vir, Rif, Sm and Su designate to virulence to mulberry, resistance to rifampicin, streptomycin and sulfonamide, respectively. hsdM and hsdR designate host-controlled modification and restriction, respectively; thi stands for thiamine. 
on mulberry. Spontaneous rifampicin resistant mutants were obtained by plating ca. $10^{10}$ cells on $\mathrm{KB}$ agar containing $100 \mu \mathrm{g} / \mathrm{ml}$ rifampicin.

Detection of plasmids. Bacteria were grown overnight in liquid $\mathrm{KB}$ medium at $30 \mathrm{C}$ and cleared lysate containing plasmid DNA was extracted according to the method of Birnboim and Doly $(1979)^{1)}$. Plasmid DNA were analysed by electrophoresis at 50 $\mathrm{mA}$ and 100 volts in $0.7 \%$ agarose (Sigma, Type I, Low EEO) gel with Tris-borate buffer ( $89 \mathrm{mM}$ Tris base, $2.5 \mathrm{mM}$ disodium EDTA and $8.9 \mathrm{mM}$ boric acid). The gels were stained with ethidium bromide $(1 \mu \mathrm{g} / \mathrm{ml})$ and photographed under short wave UV illumination. The sizes of the plasmids were estimated by comparison with eight bands of the plasmids in E. coli V 517 (Macrina et $a l .{ }^{6)}$ ) in the same gel.

Plasmid transfers. Overnight cultures of donor and recipient cells were mixed in the ratio of $1: 1$ and collected on $0.45 \mu \mathrm{m}$ Millipore filter. The filters were, then, incubated on $\mathrm{KB}$ agar at $30 \mathrm{C}$ for 5 to $12 \mathrm{hr}$. After mating, cells were washed and resuspended in $1 \mathrm{ml}$ of sterile distilled water and $0.1 \mathrm{ml}$ of appropriate dilutions were plated on selective media. Donor and recipient cells were plated separately on the same selective media as the controls.

\section{Results}

\section{Detection of indigenous plasmids in Pseudomonas syringae pv. mori}

DNA extracted from 17 isolates of $P$. s. mori contained 2 to 4 indigenous plasmids whose size ranged from approximately 4.5 to $70 \mathrm{mdal}$ (Fig. 1, Table 2). Although the detail relationships among the plasmids were not examined, 8 classes were distinguished based on their size. Thereby, P. s. mori tested here was classified into 9 groups based on their plasmid patterns (Table 2). Definite role of each plasmid determining some phenotypes such as toxigenicity of halo blight producing strains, phage sensitivity and carbohydrate (rhamnose or xylose) utilization could not be established. But all the halo

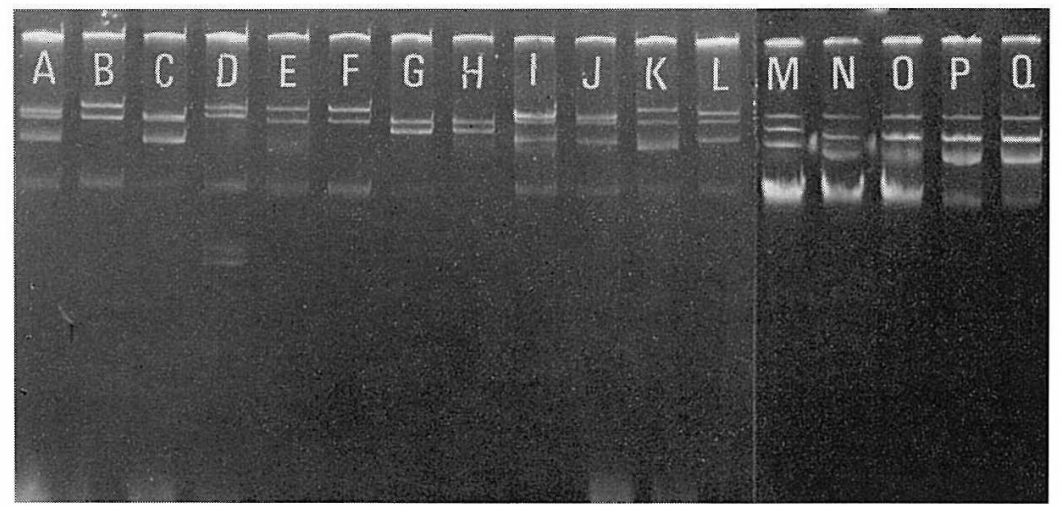

Fig. 1. Agarose gel $(0.7 \%)$ electrophoresis of indigenous plasmid DNA from Pseudomonas syringae pv.mori.

Sample wells contained DNA from strains S6801(A), S6802(B), S6803(C), S6804(D), S6805(E), S6806(F), S6807(G), S6808(H), S6809(I), S6810(J), M5(K) and S6914-1(L), and halo blight strains S7133-2(M), S7133-3(N), S7233-1(O) S7233-2(P) and S7233-3(Q). The diffuse band present in all wells is chromosomal DNA. 
Table 2. Classification of Pseudomonas syringae pv. mori strains according to plasmid content and an association between plasmid and some phenotypes

\begin{tabular}{|c|c|c|c|c|c|c|c|c|c|c|c|c|c|c|}
\hline \multirow{2}{*}{$\begin{array}{l}\text { Bacterial } \\
\text { isolates }\end{array}$} & \multirow[b]{2}{*}{$\mathrm{A}$} & \multicolumn{6}{|c|}{ Plasmid content ${ }^{\mathrm{a})}$} & \multirow[b]{2}{*}{$\mathrm{H}$} & \multirow{2}{*}{\multicolumn{2}{|c|}{$\begin{array}{l}\text { No. of } \\
\text { plasmid Grouping }\end{array}$}} & \multirow{2}{*}{$\begin{array}{l}\text { Halo } \\
\text { toxin }\end{array}$} & \multirow{2}{*}{ Lysotype } & \multicolumn{2}{|c|}{ Decomposition $^{\text {d) }}$ of } \\
\hline & & B & $\mathrm{C}$ & $\mathrm{D}$ & $\mathrm{E}$ & $\mathrm{F}$ & G & & & & & & Rhamnose & Xylose \\
\hline $\mathrm{S} 6801$ & - & + & + & - & - & + & - & - & 3 & I & - & $\mathrm{E}$ & + & + \\
\hline S6802 & + & - & + & - & - & - & - & - & 2 & II & - & $\mathrm{C}$ & - & + \\
\hline S6803 & - & - & $\left.H^{e}\right)$ & - & - & + & - & - & 3 & III & - & $\mathrm{C}$ & - & - \\
\hline S6804 & + & + & - & - & - & - & + & + & 4 & $\mathrm{~N}$ & - & $\mathrm{B}$ & + & + \\
\hline S6805 & + & - & + & - & - & - & - & - & 2 & II & - & Un-determined & - & + \\
\hline S6806 & + & - & + & - & - & - & - & - & 2 & II & - & $\mathrm{C}$ & - & + \\
\hline S6807 & - & - & + & + & - & - & - & - & 2 & $\mathrm{~V}$ & - & A & + & + \\
\hline S6808 & - & - & + & + & - & - & - & - & 2 & V & - & $\mathrm{E}$ & + & + \\
\hline S6809 & - & + & + & - & - & + & - & - & 3 & I & - & B & + & + \\
\hline S6810 & - & + & + & - & - & + & - & - & 3 & I & - & B & + & + \\
\hline M5 & + & - & + & - & - & + & - & - & 3 & VI & - & $N^{f}{ }^{f}$ & NT & NT \\
\hline S6914-1 & - & + & + & - & - & + & - & - & 3 & VII & - & $\mathrm{A}$ & NT & NT \\
\hline S7133-2 & + & - & + & - & + & - & - & - & 3 & VIII & + & NT & NT & $\mathrm{NT}$ \\
\hline S7133-3 & + & - & - & + & - & + & - & - & 3 & $\mathbb{X}$ & + & NT & NT & NT \\
\hline S7233-1 & + & - & - & + & - & + & - & - & 3 & $\mathbb{X}$ & + & NT & NT & NT \\
\hline S7233-2 & + & - & - & + & - & + & - & - & 3 & $\mathbb{X}$ & + & $\mathrm{NT}$ & NT & NT \\
\hline S7233-3 & + & - & - & + & - & + & - & - & 3 & $\mathbb{X}$ & + & $\mathrm{NT}$ & NT & NT \\
\hline
\end{tabular}

a) Molecular weight of plasmids determined by coelectrophoresis with a DNA standard of $E$. coli V5176) is following: A ; 70 mdal, B ; $60 . \mathrm{C} ; 50, \mathrm{D} ; 35, \mathrm{E} ; 28, \mathrm{~F} ; 25, \mathrm{G} ; 4.8, \mathrm{H} ; 4.5$.

b) Grouping by plasmid pattern.

c) Lysotype has been determined by the drop method using 6 strains of virulent phage in $P$. $s$. mori $^{13)}$.

d) That has been examined by production of acid on Ayers' medium with each carbohydrate ${ }^{14}$.

e) Two plasmids, very similar in size.

f) Not tested.

blight-causing strains contained the largest plasmid designated A, although some nonhalo producing strains also had this plasmid.

\section{Conjugative mobilization of RSF1010 from Pseudomonas syringae pv. mori to Esherichia coli}

The large size of several of the P. s. mori plasmids suggested that they may be conjugative. This was tested in an indirect way: A non-conjugative but mobilizable plasmid RSF1010, which encodes for streptomycin- and sulfonamide-resistance, was introduced into rifampicin resistant mutant of $P$. s. mori by mating with $P$. syringae pv. tabaci BR2(RSF1010). BR2 contains the indigenous conjugative plasmid pBPW1 which mobilizes RSF1010 readily to a number of bacteria. After mating, RSF1010* transconjugants were selected by plating on $\mathrm{KB}$ agar with rifampicin $(100 \mu \mathrm{g} / \mathrm{ml})$ and streptomycin $(20 \mu \mathrm{g} / \mathrm{ml})$. The presence of RSF1010 and the absence of pBPWl in the transconjugants were confirmed by observing the corresponding bands of DNA extracts on agarose gel electrophoresis. RSF1010 was transferred in this way to all the isolates of $P$. s. mori examined at frequencies of $1.2 \times 10^{-1}$ to $1.8 \times 10^{-5}$ per recipient cell.

Transconjugants containing RSF1010 but not pBPWl were subsequently mated with E. coli SK1592 selecting for transfer of streptomycin resistance. Transmission of RSF 1010 was again confirmed by gel electrophoresis. All isolates except S6809 were 
Table 3. Conjugative mobilization of RSF1010 from Pseudomonas syringae pv. mori to Escherichia coli SK1592

\begin{tabular}{lccccc}
\hline $\begin{array}{l}\text { P. syringae pv. } \\
\text { mori (donor) }\end{array}$ & $\begin{array}{c}\text { Transfer frequency } \\
\text { per recipient cell }\end{array}$ & \multicolumn{3}{c}{$\begin{array}{c}\text { Characterization of } \\
\text { the transconjugants }\end{array}$} \\
\hline S 6801 rif (RSF1010) & $1.6 \times 10^{-5}$ & Su & Sm & RSF1010 \\
S 6802 rif (RSF1010) & $5.9 \times 10^{-8}$ & + & + & + \\
S 6803 rif (RSF1010) & $1.5 \times 10^{-9}$ & + & + & + \\
S 6804 rif (RSF1010) & $1.8 \times 10^{-8}$ & + & + & + \\
S 6805 (RSF1010) & $3.1 \times 10^{-8}$ & + & + & + \\
S 6809 rif (RSF1010) & ND $^{\mathrm{c}}$ rif & & & + \\
M 5 rif (RSF1010) & $2.0 \times 10^{-8}$ & + & + & + \\
S 6914-1 rif (RSF1010) & $1.2 \times 10^{-9}$ & + & + & + \\
S 7133-2 rif (RSF1010) & $1.9 \times 10^{-9}$ & + & + & + \\
S 7133-3 rif (RSF1010) & $5.5 \times 10^{-9}$ & + & + & + \\
S 7233-1 rif (RSF1010) & $2.0 \times 10^{-9}$ & + & + & + \\
S 7233-2 rif (RSF1010) & $6.3 \times 10^{-9}$ & + & + & + \\
S 7233-3 rif (RSF1010) & $4.1 \times 10^{-9}$ & + & + & + \\
\hline
\end{tabular}

a) $\mathrm{Su}$ : Resistant to sulfonamide, $\mathrm{Sm}$ : Resistant to streptomycin. Presense of RSF 1010 was confirmed by agarose gel electrophoresis.

b) S6805 (RSF1010) was obtained by the transformation with RSF1010 from Pseudomonas putida AC 808. All other strains were constructed by mating with P. s. tabaci BR2(RSF1010), but none of them contained the pBPW1 plasmid indigenous to this strain.

c) Not detectable.

capable of donating RSF1010 in these crosses although at exceedingly low frequency (Table 3). This suggests that the strains tested possess an indigenous fertility system. However, this system either is hardly utilized to mobilize RSF1010 or is naturally repressed.

\section{Discussion}

Our studies showed that plasmids are ubiquitous among $P$. s. mori strains as in other plant pathogenic bacteria. At present, their functions are unknown and no apparent correlations between these plasmids and phage sensitivity, carbohydrate utilization, pathogenicity or fertility properties were noted in our studies. However, there may be a correlation among plasmid A and toxin production, because all "halo" strains have this plasmid. In order to clarify the functions of plasmid A and of the others, however, further studies and datailed molecular characterization of them are necessary. Unlike some plasmids in other plant pathogenic bacteria ${ }^{3,16)}, P$. s. mori plasmids do not appear to have derepressed fertility functions, as judged by their inability to mobilize RSF1010. This conclusion is further supported by the inability to demonstrate the transmission of the transposable element Tn7 from $P$. s. mori strains to E. coli and the other bacteria even in the presence of conjugative plasmid RPl, while transmission of this element can be clearly demonstrated in $P$. s. tabaci BR 2 carrying the pBPWl plasmid, whether the transposon is inserted either into pBPWl itself or into the chromosome of this bacterium (Sato et al. ${ }^{15)}$ and our unpublished data). At least some $P$. s. mori strains tested were 
ineffective donors of plasmid RPl even though they accepted the plasmid freely by conjugation. We speculate that these strains may be "fertility sinks" for transmissible plasmids. However, they clearly have good recipient ability for the pBPWl mating system and for RPl too as well. Our findings of the ability to obtain transposon insertions ${ }^{15)}$ and of the ability of RSF1010, useful cloning vector, to replicate stably in $P$. s. mori strains will permit us further genetic studies of this bacterium.

\section{Literature cited}

1. Birnboim, H. C. and Doly, J. (1979). Nucl. Acids Res. $7: 1513-1523$.

2. Comai, L. and Kosuge, T. (1980). J. Bacteriol. 143: 950-957.

3. Coplin, D. L. and Rowan, R. G. (1978). Proc. 4th Int. Conf. Plant Path. Bact. Aug. 28 -Sep. 2, Angers, France Vol 1:67-73.

4. King, E. O., Ward, M. K. and Raney, D. E. (1954). J. Lab. Clin. Med. 44:301-307.

5. Lacy, G. H. and Leary, J. V. (1979). Ann. Rev. Phytopathol. 17:181-202.

6. Macrina, F. L., Kopecko, D. J., Jones, K. R., Ayers, D. J. and McCowen, S. M. (1978). Plasmid $1: 417-420$.

7. Miller, J.H. (1972). Experiment in Molecular Genetics. Cold Spring Harber Laboratory, N. Y. $466 \mathrm{p}$.

8. Panopoulos, N. J., Guimaraes, W. V., Hua, S. S., Sabersky-Lehman, C., Resnik, S., Lai, M. and Shaffer, S. (1978). Microbiology 1978 (Schlessinger, D. ed.). Amer. Soc. for Microbiol., Washington, D. C. pp. 238-241.

9. Panopoulos, N. J. and Staskawicz, B. J. (1981). In Toxin in Plant Disease (Durbin, R. D. ed.). Academic Press, N. Y. pp. 79-107.

10. Panopoulos, N. J., Staskawicz, B. J. and Sandlin, D. (1979). In Plasmids of Medical, Environmental and Commercial Importance (Timmis, K. N. and Pühler, A. eds.). Elsevier/NorthHolland Biomedical Press, Amsterdam. pp. 365-372.

11. Sato, M. (1978). Ann. Phytopath. Soc. Japan $44: 255-261$.

12. Sato, M. and Takahashi, K. (1973). Ibid. 39:425-428.

13. Sato, M. and Takahashi, K. (1976). J. Sericult. Sci. Japan 45:150-155.

14. Sato, M., Takahashi, K. and Wakimoto, S. (1971). Ann. Phytopatho. Soc. Japan $37: 128-135$.

15. Sato, M., Staskawicz, B. J., Panopoulos, N. J., Peters, S. and Homma, M (1981). Plasmid 6 : 325-331.

16. Staskawicz, B. J., Sato, M. and Panopoulos, N. J. (1981). Phytopathology $71: 257$.

17. Takahashi, K. and Sato, M. (1977). Ann. Phytopath. Soc. Japan 43:593-597.

18. Van Larebeke, N., Genetel-o, C., Schell, J., Schilperoort, R. A., Hermans, A. K., Hernalstteens, J.P. and Van Montagu, M. (1975). Nature $255: 742-743$.

19. Watson, B., Currier, T., Gordon, M. P., Chilton, M. D. and Nester, E. W. (1975). J. Bacteriol. $123: 255-264$.

20. Yano, H., Fujii, H., Mukoo, H., Fukuyasu, T., Terakado, N. and Isayama, Y. (1979). Ann. Phytopath. Soc. Japan $45: 201-206$. 
和 文 摘 要

クワ縮葉細菌病菌 Pseudomonas syringae pv. mori のプラスミド

\section{佐藤 守・Brian J. StASKAWICZ • Nickolas J. PANOPOULOS}

クワ縮葉細菌病菌 Pseudomonas syringae pv. mori の各菌株は, 分子量約 4.5 70メガダルトンのプラ スミドを，それぞれ $2 \sim 4$ 個，保有していた。供試17菌株は，そのプラスミドパターンから 9 群に分けるこ とができた。これらプラスミドパターンとハロー毒素産生能，ファージ感受性あるいは他の性状との間には 明らかな関係を認められなかった。

供試したすべての菌株は，P. syringae pv. tabaci BR2 の伝達性プラスミド pBPW1 によって非伝達性 プラスミド RSF1010 を高頻度に受容し，かつ，それを大腸菌（受容菌）に，非常に低率ではあるが，再伝 達した。このことは，本菌のプラスミドが抑制された状態で存在するか，あるいは RSF1010を低率で可動 化できる固有の接合システムをもっていることを示している。 